\title{
ORIGINAL ARTICLE \\ Greenhouse gas emissions of realistic dietary choices in Denmark: the carbon footprint and nutritional value of dairy products
}

\author{
Louise Bruun Werner'* Anna Flysjö ${ }^{2}$ and Tine Tholstrup' \\ 'Department of Nutrition, Exercise and Sports, Faculty of Sciences, University of Copenhagen, Copenhagen, Denmark; \\ ${ }^{2}$ Arla Foods, Viby J, Denmark
}

Abstract

Background: Dairy products are important in a healthy diet due to their high nutritional value; they are, however, associated with relatively large greenhouse gas emissions (GHGE) per kg product. When discussing the need to reduce the GHGE caused by the food system, it is crucial to consider the nutritional value of alternative food choices.

Objective: The objective of this study was to elucidate the role of dairy products in overall nutrition and to clarify the effects of dietary choices on GHGE, and to combine nutritional value and GHGE data.

Methods: We created eight dietary scenarios with different quantity of dairy products using data from the Danish National Dietary Survey (1995-2006). Nutrient composition and GHGE data for 71 highly consumed foods were used to estimate GHGE and nutritional status for each dietary scenario. An index was used to estimate nutrient density in relation to nutritional recommendation and climate impact for solid food items; high index values were those with the highest nutrient density scores in relation to the GHGE.

Results: The high-dairy scenario resulted in $27 \%$ higher protein, $13 \%$ higher vitamin D; $55 \%$ higher calcium; $48 \%$ higher riboflavin; and 18\% higher selenium than the non-dairy scenario. There was a significant correlation between changes in calcium and changes in vitamin $\mathrm{D}$, selenium, and riboflavin content $(P=0.0001)$ throughout all of the diets. The estimated GHGE for the dietary scenario with average-dairy consumption was $4,631 \mathrm{~g} \mathrm{CO}_{2} \mathrm{e} /$ day.

Conclusions: When optimizing a diet with regard to sustainability, it is crucial to account for the nutritional value and not solely focus on impact per $\mathrm{kg}$ product. Excluding dairy products from the diet does not necessarily mitigate climate change but in contrast may have nutritional consequences.

Keywords: sustainable diet; dairy products; nutrient density; nutrient recommendations; greenhouse gas emission

Received: 22 February 20।3; Revised: 20 August 20।3; Accepted: 6 May 20I4; Published: 10 June 2014

$\mathrm{D}$ uring the next decades, this planet will have to be able to feed and sustain 9 billion people. This will put significant pressure on the food production system. It is therefore essential that our resources are used efficiently and that the negative environmental impacts from production are reduced. One of the great challenges is to reduce the greenhouse gas emissions (GHGE). At the same time, it is equally critical that we produce and provide nutritious food. Hence, sustainable diets must be based on nutritional value and not only on energy content. Public health messages for recommended dietary intakes have focused on the impact on health outcomes while all the wider issues relating to sustainability still remain relatively unexplored. However, the concept of a sustainable diet is neither new nor simple $(1,2)$, rather a complex issue including environmental, economic, and social aspects (3).

Animal-based products are generally associated with relatively large GHGE on a per $\mathrm{kg}$ basis. There has been a belief that consumers can make a positive contribution to reduce the environmental impact by replacing animalbased products, especially meat and dairy products, with vegetarian products $(4,5)$. However, a recent study estimating the GHGE from self-selected diets of a sample of adults in France showed that several scenarios related to the reduction of both caloric intakes and meat consumption are not necessarily the best approach to decreasing diet-related GHGE (6). In addition, some researchers have concluded that reducing GHGE by changing food production processes result in more profound changes $(7,8)$.

Reducing or excluding animal-based products, which make the greatest contribution to GHGE in the diets (4, 6,8 ), is an inevitable policy option. However, reducing or excluding these products from the diet, which are unique sources of specific and essential nutrients, raises many nutritional challenges (9). In addition, when optimizing a diet with regard to sustainability, it is crucial to account 
for the nutritional value and not solely focus on impacts per $\mathrm{kg}$ products, because any dietary recommendations to reduce GHGE must also meet dietary requirements. Models that track the environmental impact of foods in the context of the nutritional benefits they offer are being developed. Recently, an index was proposed which explores nutrient density of beverages related to climate impact - it showed that milk performed better than other beverages (10). Moreover, two studies have demonstrated that a sustainable diet that meets the dietary requirements for heath combined with lower GHGE can be achieved without eliminating meat or dairy products $(11,12)$.

Dairy products are part of dietary recommendations in many countries (13-15). The dietary guidelines of United States Department of Agriculture (USDA) recommend three daily servings of low-fat dairy products for adults, corresponding to $720 \mathrm{ml}$ (15). Dairy products contribute with high-quality protein as well as calcium and several other essential nutrients. On the contrary, dairy fat is very rich in saturated fatty acids (SFA) known to raise cholesterol levels. However, the health effects of dairy products are controversial (16-20), and the majority of observational studies have failed to find an association or even an inverse association between the intake of dairy products and risk of cardiovascular diseases $(21,22)$.

In this study, we created different dietary scenarios with realistic quantities of dairy products included in order to elucidate the role of dairy products in overall nutrition and, further, to clarify the effect of dietary choices on GHGE. This was evaluated based on national intake data and carbon footprint (CF) data of 71 widely consumed food items, which were selected as representative of the Danish diet and assigned to one of the main food types in the same proportion as eaten by adults (23). The quantities of each food group were according to Danish Dietary Guidelines (DDG) (24). If not quantified by the DDG, we made assumptions based on the available literature. This study only includes natural foodstuffs and supplements and fortified foodstuffs were excluded as they are not part of the recommendations. Although this is a theoretical study, based on dietary data and associated GHGE, the results contribute with new knowledge to how dairy products can contribute to a healthy and sustainable diet.

\section{Materials and methods}

\section{Food consumption and GHGE data}

This study relies on nutrient composition data of 71 widely consumed food items, which are representative for the diet of the Danish population, as well as the associated GHGE of each food item.

\section{Food consumption data}

We used dietary data for women $(n=3,165)$ collected from the Danish National Dietary Survey (DNDS) conducted from 1995 to 2006, including the average intake (in grams per day) of a majority of food items (25).

\section{GHGE data}

The GHGE estimates, also referred to as the CF, for each of the 71 food items are taken from the literature. GHGE associated with food production primarily consist of nitrous oxide $\left(\mathrm{N}_{2} \mathrm{O}\right)$, methane $\left(\mathrm{CH}_{4}\right)$, and fossil carbon dioxide $\left(\mathrm{CO}_{2}\right)$, where the first two gases are related to primary production. Although biogenic $\mathrm{CO}_{2}$ emissions from land use and land use change (LULUC) can also be significant for food production $(26,27)$, the present paper does not include emissions from LULUC due both to large uncertainties in data (as it is difficult to estimate carbon stocks and measure carbon fluxes) and the lack of agreed methodology on how to account for these emissions. To assess the total GHGE from primary production (including production of all inputs) to final consumption, the method life cycle assessment (LCA) is used $(28,29)$. The total amount of GHGE is expressed as $\mathrm{CO}_{2}$ equivalents $\left(\mathrm{CO}_{2} \mathrm{e}\right)$ assuming a 100 -year perspective, where $1 \mathrm{~kg} \mathrm{CO}$ equals $1 \mathrm{~kg} \mathrm{CO}_{2} \mathrm{e}, 1 \mathrm{~kg} \mathrm{CH}_{4}$ equals $25 \mathrm{~kg} \mathrm{CO}_{2} \mathrm{e}$, and $1 \mathrm{~kg}$ $\mathrm{N}_{2} \mathrm{O}$ equals $298 \mathrm{~kg} \mathrm{CO}_{2} \mathrm{e}$ (30). It is acknowledged that there can be substantial variation in $\mathrm{CF}$ numbers due to methodological choices (e.g. 'consequential' or 'attributional' modeling $\left.{ }^{1}\right)(31,32)$ or system boundaries (e.g. whether the consumer stage is included or not) $(33,34)$. These aspects have been considered. The CF data used in the present study are selected to be representative for Denmark. Data are also gathered to the largest possible extent from studies using the same methodology (attributional modeling, recommended by, for example, BSI, 2011). In addition, the CF numbers are verified by comparing different sources when possible. In many $\mathrm{CF}$ studies, the consumer stage is not included. To harmonize the system boundaries, the latter stage of the life cycle is added in the studies where this is not accounted for (transport from retail to consumer and, if relevant, preparation of the food). Data on home transport is estimated as $0.1 \mathrm{~kg} \mathrm{CO}_{2} \mathrm{e}$ per $\mathrm{kg}$ food $(35,36)$ and preparation of food is taken from Carlsson-Kanyama and Boström-Carlsson (37). There is great variation both within and between different food types. The CF per $\mathrm{kg}$ of edible food is about $0.2-4 \quad \mathrm{~kg} \mathrm{CO}_{2} \mathrm{e}$ for fruit and vegetables; 0.6-5 $\mathrm{kg} \mathrm{CO} \mathrm{CO}_{2} \mathrm{e}$ for potato, rice, and pasta; 0.9-2 $\mathrm{kg} \mathrm{CO}_{2} \mathrm{e}$ for bread and cereals; around $1 \mathrm{~kg} \mathrm{CO}_{2} \mathrm{e}$ for milk and yoghurt; $1-10 \mathrm{~kg} \mathrm{CO}$ e for 'leeway' (e.g. candy, cakes, pizza); 3-10 $\mathrm{kg} \mathrm{CO}_{2} \mathrm{e}$ for cheese; and 5-30 $\mathrm{kg} \mathrm{CO}_{2} \mathrm{e}$ for meat (poultry, pork, and beef) $(10,26,34,38-61)$. A summary of the CF data on foods used in the present

\footnotetext{
$\overline{{ }^{1} \text { Attributional modeling uses average data and distributes emissions }}$ between co-products by allocation, opposed to consequential modeling that uses marginal data and so-called system expansion (to avoid allocation by expanding the system to include the additional functions related to co-products).
} 
Table 1. Greenhouse gas emission excluding and including waste at consumer level $\left(\mathrm{kg} \mathrm{CO}_{2} \mathrm{e}\right.$ per $\left.\mathrm{kg}\right)$ for each food item used in the study

\begin{tabular}{|c|c|c|c|}
\hline \multirow[b]{2}{*}{ Food types } & \multirow{2}{*}{$\begin{array}{c}\text { Representative } \\
\text { Food items }\end{array}$} & \multicolumn{2}{|c|}{ Consumer level } \\
\hline & & $\begin{array}{c}\text { Excluding } \\
\text { waste }\end{array}$ & $\begin{array}{c}\text { Including } \\
\text { waste }\end{array}$ \\
\hline \multirow[t]{11}{*}{ Vegetables } & Carrot & 0.22 & 0.27 \\
\hline & Cabbage (white) & 0.29 & 0.36 \\
\hline & Red cabbage & 0.29 & 0.36 \\
\hline & Brussels sprouts & 0.29 & 0.36 \\
\hline & Cauliflower & 0.61 & 0.76 \\
\hline & Broccoli & 1.67 & 2.06 \\
\hline & Pear & 0.59 & 0.73 \\
\hline & Onion & 0.48 & 0.60 \\
\hline & Lettuce (iceberg) & 0.45 & 0.56 \\
\hline & Tomato & 2.60 & 3.21 \\
\hline & Cucumber & 3.00 & 3.70 \\
\hline \multirow[t]{4}{*}{ Fruits } & Apple & 0.60 & 0.74 \\
\hline & Orange & 0.80 & 0.99 \\
\hline & Banana & 1.22 & 1.51 \\
\hline & Pear & 0.60 & 0.74 \\
\hline Juice & Apple juice & 0.71 & 0.71 \\
\hline \multirow{2}{*}{$\begin{array}{c}\text { Meat and } \\
\text { meat }\end{array}$} & Beef & 27.99 & 31.45 \\
\hline & Pork & 5.57 & 6.25 \\
\hline products & Chicken & 5.21 & 5.85 \\
\hline \multirow{4}{*}{$\begin{array}{c}\text { Bread and } \\
\text { cereals }\end{array}$} & Wheat bread, coarse & 1.10 & 1.47 \\
\hline & Wheat bread, fine & 1.50 & 2.00 \\
\hline & Rye bread & 0.90 & 1.20 \\
\hline & Oatmeal & 0.90 & 1.20 \\
\hline \multirow{3}{*}{$\begin{array}{l}\text { Potatoes, } \\
\text { pasta, rice }\end{array}$} & Potatoes & 0.57 & 0.69 \\
\hline & Pasta & 1.93 & 2.57 \\
\hline & Rice & 3.74 & 4.99 \\
\hline \multirow[t]{2}{*}{ Fish } & Cod & 4.47 & 5.02 \\
\hline & Herring & 1.47 & 1.65 \\
\hline Eggs & Eggs & 2.10 & 2.21 \\
\hline \multirow[t]{3}{*}{ Fats } & Olive oil & 2.20 & 2.29 \\
\hline & Corn oil & 2.20 & 2.29 \\
\hline & Margarine, $60 \%$ fat & 1.66 & 1.75 \\
\hline \multirow{4}{*}{$\begin{array}{c}\text { Milk and milk } \\
\text { products }\end{array}$} & Mini milk, $0.5 \%$ fat & 1.09 & 1.17 \\
\hline & Skim milk, $0.3 \%$ fat & 1.09 & 1.17 \\
\hline & Butter milk, $0.5 \%$ fat & 1.24 & 1.33 \\
\hline & Yoghurt, $0.5 \%$ fat & 1.24 & 1.33 \\
\hline \multirow{4}{*}{$\begin{array}{l}\text { Cheese } \\
\text { products }\end{array}$} & Cheese $20+, 17 \%$ fat & 8.47 & 9.11 \\
\hline & Cheese $30+, 31 \%$ fat & 9.23 & 9.93 \\
\hline & Cheese, smoked & 6.05 & 6.50 \\
\hline & Cheese, cottage $20+, 4 \%$ fat & 3.44 & 3.70 \\
\hline Marmalade & Marmalade & 1.60 & 1.60 \\
\hline \multirow[t]{4}{*}{ Soft drinks } & Mineral water, added sugar & 1.00 & 1.00 \\
\hline & Mineral water, unsweetened & 1.00 & 1.00 \\
\hline & Lemonade, added sugar & 1.00 & 1.00 \\
\hline & Lemonade, unsweetened & 1.00 & 1.00 \\
\hline \multirow[t]{3}{*}{ Beverages } & Water & 0.10 & 0.10 \\
\hline & Tea & 0.33 & 0.33 \\
\hline & Coffee & 0.33 & 0.33 \\
\hline
\end{tabular}

Table 1. (Continued)

\begin{tabular}{|c|c|c|c|}
\hline \multirow[b]{2}{*}{ Food types } & \multirow{2}{*}{$\begin{array}{c}\text { Representative } \\
\text { Food items }\end{array}$} & \multicolumn{2}{|c|}{ Consumer level } \\
\hline & & $\begin{array}{l}\text { Excluding } \\
\text { waste }\end{array}$ & $\begin{array}{l}\text { Including } \\
\text { waste }\end{array}$ \\
\hline $\begin{array}{l}\text { Vegetable } \\
\text { drink }\end{array}$ & Soy drink & 0.40 & 0.43 \\
\hline \multirow[t]{3}{*}{ Beans } & Beans, brown & 1.24 & 1.29 \\
\hline & Beans, white & 1.24 & 1.29 \\
\hline & Beans, soy & 1.24 & 1.29 \\
\hline Alcoholic & Beer & 1.10 & 1.10 \\
\hline drinks & Wine & 2.20 & 2.20 \\
\hline \multirow[t]{16}{*}{ Leeway } & $\begin{array}{l}\text { Dark chocolate, including } \\
\text { marzipan }\end{array}$ & 1.00 & 1.00 \\
\hline & Licorice & 2.60 & 2.60 \\
\hline & Sweets & 2.60 & 2.60 \\
\hline & Chewing gum & 2.60 & 2.60 \\
\hline & Pastry & 2.50 & 2.50 \\
\hline & Tebirkes & 2.50 & 2.50 \\
\hline & Croissant & 4.00 & 4.00 \\
\hline & Cream cake & 2.50 & 2.50 \\
\hline & Chocolate cake & 2.50 & 2.50 \\
\hline & Biscuit & 2.50 & 2.50 \\
\hline & Ice cream & 2.80 & 2.80 \\
\hline & Lollies & 2.60 & 2.60 \\
\hline & Burger & 10.00 & 10.00 \\
\hline & Hot dog & 2.50 & 2.50 \\
\hline & Pita & 2.50 & 2.50 \\
\hline & Pizza & 2.50 & 2.50 \\
\hline
\end{tabular}

study is found in Table $1(10,26,34,38-61)$. Food waste, especially at the consumer level, has been gaining attention over the past few years $(62,63)$. It is estimated that around one third of all food produced is not consumed, and the largest share in industrialized countries of this food waste occurs at consumer level (62). Table 1 shows CF numbers both excluding and including waste at the consumer level. When CF data has only been available for primary production, food waste has been estimated for the rest of the value chain based on a study from the Food and Agriculture Organization of the United Nations, FAO (62). In the present study, CF numbers including food waste at the consumer level are used to calculate total GHGE as well as their absolute and relative contribution. However, we have also analyzed the GHGE excluding food waste in this study.

\section{Creating different dietary scenarios}

Creating a 'base' diet

We created a realistic and healthy 'base' diet representing the dietary requirements of an adult woman $(9.2 \mathrm{MJ})$ with a sedentary lifestyle and who undertakes limited physical activity in her leisure time (PAL, Physical Activity Level =1.6) in the age range 31-60 (64). The age group 
for women was chosen based on the prevailing health and nutritional problems. It has been recognized that the pregnant and lactating women form one of the most nutritionally vulnerable segments of the population. For example, women in this age group have higher iron requirement than men. The first step was to create the diet in agreement with the DDG (24). The DDG mainly aim to communicate the concept of a healthy diet in order to increase the population's intake of fruit and vegetables, fish, potatoes, rice or pasta, as well as whole meal bread, to limit the intake of added sugar from sugar-containing soft drinks, cake and candy, and to limit the intake of fat, especially animal fat (24). In order to create a whole diet, we categorized the 71 food items into different main food types (e.g. fruit, vegetables, meat, and fish).

Table 2 shows the main food types used to create the different dietary scenarios, the recommended intake according to the DDG, and the quantities used in the diets as well as any specifications. The DDG quantify the intake of fruit, vegetables, fish, bread, cereals, potatoes, pasta and rice, but not the intake of meat, milk, cheese, and eggs, or the intake of sugar, sugary foods, fat, or fatty foods (24). If not quantified by the DDG, we made assumptions based on the available literature, as discussed below (Table 2). The next step was to create the composition of the main food types using data for DNDS. The most widely consumed food items in each food type were selected as representative of Danish diets. For example, according to national intake data, we consume $164 \mathrm{~g}$ fruit per day including 10 different fruits. Of the $164 \mathrm{~g}$ of fruit, $128 \mathrm{~g}$ represent apple $(58 \mathrm{~g})$, pear $(20 \mathrm{~g})$, orange $(21 \mathrm{~g})$, and banana $(29 \mathrm{~g})$, and the last $36 \mathrm{~g}$ are divided into kiwi, grapes, melon, peach, pineapple, and berries (23). As the intake of apple, pear, orange, and banana were much higher compared to the six other fruits, these food items were selected as representative of this food type. Moreover, the compositions of each food type are composed in the same proportion as eaten. For example, $100 \mathrm{~g}$ of fruit include $45.3 \mathrm{~g}$ apple, $15.6 \mathrm{~g}$ pear, $16.4 \mathrm{~g}$ orange, and $22.7 \mathrm{~g}$ banana. In this way, each food type was based on actual food choices and composed in the same proportion as eaten by adults. The consumption of some food items in DNDS was deficient. In this case, we made assumptions based on the literature as mentioned below (Table 2).

According to the DDG, $600 \mathrm{~g}$ fruits and vegetables are recommended, corresponding to three fruits and three vegetables of around $100 \mathrm{~g}$ per piece (65). This recommendation is based on the minimum amount at which

Table 2. Danish Dietary Guidelines 2005 and food intake patterns for women, by food types, quantities, and specifications

\begin{tabular}{|c|c|c|c|}
\hline \multirow[b]{2}{*}{ Food types } & \multirow{2}{*}{$\begin{array}{l}\text { DDG } 2005 \\
\text { recommended intake }\end{array}$} & \multicolumn{2}{|c|}{ Food intake pattern used to create dietary scenarios } \\
\hline & & Amounts & Specifications \\
\hline Vegetables & 600 g per day & 300 g per day & Half of the vegetables are coarse ${ }^{*}$ \\
\hline Fruits & & 250 g per day & Fresh fruit \\
\hline Juice & & 50 g per day & $\begin{array}{l}\text { A glass of juice counts as one of the recommended } \\
\text { Six units of fruit and vegetables }\end{array}$ \\
\hline Bread and cereals & 500 g per day & 250 g per day & $\begin{array}{l}\text { Half of the bread and cereals are fiber-rich } \\
\text { Predominantly bread and moderate amount of cereals }\end{array}$ \\
\hline Potatoes, pasta, rice & & 250 g per day & Predominantly potatoes \\
\hline Fish & 200-300 g per week & 300 g per week/42 g per day & Half oily fish and half lean fish \\
\hline $\begin{array}{l}\text { Meat and meat } \\
\text { products }\end{array}$ & Not specified & 100 g per day & $\begin{array}{l}\text { Including beef, pork and chicken } \\
\text { Maximum } 10 \mathrm{~g} \text { fat per } 100 \mathrm{~g}\end{array}$ \\
\hline Fats & Not specified & 30 g per day & Half margarine and half oils \\
\hline Eggs & Not specified & 25 g per day & Whole eggs \\
\hline Milk and milk products & Not specified & Various amounts & $\begin{array}{l}\text { Low fat milk and milk products ( } \leq 0.5 \mathrm{~g} \text { fat per } \mathrm{l} 00 \mathrm{~g} \text { ), predominantly } \\
\text { milk }\end{array}$ \\
\hline Cheese products & Not specified & Various amounts & Low fat cheese products ( $\leq 18 \mathrm{~g}$ fat per $100 \mathrm{~g}$ ) \\
\hline Marmalade & Not specified & Various amounts & Strawberry jam \\
\hline Water, tea and coffee & $\mathrm{I}-\mathrm{I} .5 \mathrm{~L}$ per day & I L per day & Predominantly water and moderate amount of coffee and tea \\
\hline Alcoholic drinks & Not specified & Various amounts & Beer and wine \\
\hline Soy drink & Not specified & Various amounts & Unfortified \\
\hline Soft drinks & Not specified & Various amounts & Soft drinks and lemonade with added sugar and unsweetened \\
\hline Leeway & Not specified & $9 \mathrm{E} \%$ & Soft drinks, candy, cake, ice cream, fast food \\
\hline Beans & Not specified & Various amounts & Brown, white and soy beans \\
\hline
\end{tabular}

DDG 2005: Danish Dietary Guidelines 2005; E\%. Percentage of energy. *Coarse vegetables are vegetables with a dietary fiber content over $2 \mathrm{~g}$ per $100 \mathrm{~g} .{ }^{\S} \mathrm{High}$ fiber-rich bread and cereals contains over $6 \mathrm{~g}$ per $100 \mathrm{~g}$. 
beneficial effects on cardiovascular disease and obesity have been observed in epidemiological studies (65). According to DDG, we decided to divide the $600 \mathrm{~g}$ per day into $300 \mathrm{~g}$ vegetables, $250 \mathrm{~g}$ fruits, and $50 \mathrm{~g}$ juice (65). Half of the vegetables ( $150 \mathrm{~g} /$ day) should be high-fiber type (i.e. containing over $2 \mathrm{~g}$ of dietary fiber per $100 \mathrm{~g}$ ) (Table 2). The DDG recommend $500 \mathrm{~g}$ per day of potatoes, rice, pasta, bread, and cereals. Half of this food type should be potatoes, rice and pasta, and half bread and cereals whereas half of the bread and cereals should be rich in fiber (i.e. containing over $6 \mathrm{~g}$ fiber per $100 \mathrm{~g}$ ) (Table 2). The DDG recommended eating at least two portions of fish a week corresponding to 200-300 g per week (half of the fish should be lean and half oily). These values are based on an evaluation balancing the positive nutritional aspects against the potential toxicological aspects. We decided to use $42 \mathrm{~g}$ fish per day corresponding to $300 \mathrm{~g}$ per week. The type of fish in the DNDS was not specified further so we decided that half of the fish should be cod and half should be herring representing lean and oily fish, respectively (Table 2).

We made assumptions about the approximate quantities of the remaining food types (e.g. meat, eggs, fat, beverages, milk, cheese, and sugary and fatty foods), which are mentioned below. Regarding meat and meat products, the amounts were estimated to be $100 \mathrm{~g}$ per day to cover the major nutrients that they supply (66). The composition of this food type includes beef, pork, and chicken which represented the most widely consumed meat types according to the DNDS (Table 2). The consumption of eggs is recommended in the context of a healthy balanced diet and no restriction of dietary eggs intake is available (67). However, individuals who have familial hypercholesterolemia, an inherited susceptibility to high blood cholesterol levels associated with a greatly increased risk of premature development of coronary heart diseases, may be particularly sensitive to dietary cholesterol intake and are advised to restrict egg consumption to two to three per week $(67,68)$. In addition, we decided to use three eggs per week. A medium egg weighs around 50-60 g which corresponds to $25 \mathrm{~g}$ per day. Regarding fat, the amount of fat used for cooking and consumed on bread was estimated to be $30 \mathrm{~g}$ per day (68). According to the Nordic Nutrition Recommendation (NNR) 2004, most dietary fat intake should be in the form of monosaturated fatty acid (MUFA) and polyunsaturated fatty acid (PUFA) such as vegetarian oils (64). In addition, it is necessary to use vegetable oils and soft plant margarines in daily cooking. We therefore included half margarine and half oils. The types of oils were unspecified in DNDS (69). We decided to use PUFArich oil (corn oil) and MUFA-rich oil (olive oil), which are both good for salads and for cooking, respectively (Table 2). The DDG recommended $1-1.5 \mathrm{~L}$ of beverages per day for adults. However, this amount may vary depending on factors such as age, size, physical activity, and climate (24).
The total amounts of non-alcoholic drinks in the diet are estimated to about $1.6 \mathrm{~L}$ per day. As for dairy products, we used the average Danish consumption of dairy products, corresponding to $322 \mathrm{~g}$ milk and milk products and $27.5 \mathrm{~g}$ cheese products (69). The DDG recommend low fat dairy products so we used milk and milk products with $\leq 0.5 \mathrm{~g}$ fat per $100 \mathrm{~g}$ and cheese products with $\leq 18 \mathrm{~g}$ fat per $100 \mathrm{~g}$ (Table 2). The food type called 'soft drinks' includes sugarsweetened beverages such as soft drinks and lemonade both with sugar added and unsweetened. We estimated the water, tea, and coffee group to $1 \mathrm{~L}$ per day to reach a total daily intake of around $1.5 \mathrm{~L}$ as recommended (23). Moreover, this was comprised predominantly of water according to DNDS (69) (Table 2). Regarding alcohol, we decided to include alcohol to make the diets realistic because alcohol is part of Danish drinking habits. The energy contribution from alcohol should not exceed 5 percentage of energy (E\%) (64). Therefore, we decided to include $200 \mathrm{~g}$ alcoholic drinks corresponding to one unit of alcohol (12 $\mathrm{g}$ alcohol), which corresponded to a maximum of $4 \mathrm{E} \%$. The majority of women's alcohol intake is in the form of wine and beer, which are consumed in almost similar amounts (23). In addition, we decided to use half beer and half wine. Realistic diets should also include nutritionally less desirable foods, referred as leeway, including energy-dense food items with high sugar and/ or fat content (e.g. candy, cake, ice cream, fast food). This food type can be eaten in moderation as part of a healthy diet, contributing to approximately $10 \%$ of the energy when the total energy level is $10 \mathrm{MJ}$ (25). In addition, the leeway contributes with $9 \mathrm{E} \%$ in this study, which is in good agreement with $10 \mathrm{E} \%$. Data on natural foodstuffs were used to minimize error and to enhance generalizability; supplements and fortified products were excluded. Very few products on the Danish market are fortified. Whereas there is no legislative requirement for fortification, Danish legislation calls for the iodine fortification of salt. Moreover, the impact of fortification on climate impact is uncertain.

Alternative dietary scenarios

In order to elucidate the role of dairy products in overall nutrition and, further, to clarify the effect of dietary choices on GHGE, we modeled on the 'base' diet (scenario 1). In total, we looked at eight dietary scenarios, six omnivorous, one vegetarian, and one vegan, with different quantities of dairy products in each. All scenarios were adjusted to have the same energy content.

Table 3 shows the dietary scenarios with different quantities of dairy products for women with an energy level of $9.2 \mathrm{MJ}$.

Scenario 1 (Average-dairy): $332 \mathrm{~g}$ milk and milk products and $27.5 \mathrm{~g}$ cheese products were included corresponding to the Danish average consumption. 
Table 3. Food intake patterns for dietary scenarios (gram per day) with different quantities of dairy products included for women with a recommended energy intake of $9.2 \mathrm{MJ}$

\begin{tabular}{|c|c|c|c|c|c|c|c|c|}
\hline Food types & Average dairy & High dairy & Milk products & Cheese products & Non-dairy & Soy drink ${ }^{\S}$ & Vegetarian & Vegan \\
\hline Vegetables & 300 & 300 & 300 & 300 & 300 & 300 & 300 & 300 \\
\hline Fruits & 250 & 250 & 250 & 250 & 250 & 250 & 250 & 250 \\
\hline Juice & 50 & 50 & 50 & 50 & 50 & 50 & 50 & 50 \\
\hline Bread and cereals & 250 & 250 & 250 & 250 & 250 & 250 & 250 & 250 \\
\hline Potatoes, pasta, rice & 250 & 250 & 250 & 250 & 250 & 250 & 250 & 250 \\
\hline Fish & 42 & 42 & 42 & 42 & 42 & 42 & 42 & 0 \\
\hline Meat and meat products & 100 & 100 & 100 & 100 & 100 & 100 & 0 & 0 \\
\hline Fats & 30 & 30 & 30 & 30 & 30 & 30 & 30 & 30 \\
\hline Eggs & 25 & 25 & 25 & 25 & 25 & 25 & 25 & 0 \\
\hline Milk and milk products & 322 & 500 & 500 & 0 & 0 & 0 & 500 & 0 \\
\hline Cheese products & 27.5 & 25 & 0 & 25 & 0 & 0 & 0 & 0 \\
\hline Marmalade & 0 & 0 & 25 & 0 & 25 & 25 & 25 & 0 \\
\hline Water, tea and coffee & 1000 & 1000 & 1000 & 1000 & 1000 & 1000 & 1000 & 1000 \\
\hline Alcoholic drinks & 200 & 200 & 200 & 200 & 200 & 0 & 200 & 200 \\
\hline Soy drink & 0 & 0 & 0 & 0 & 0 & 500 & 0 & 300 \\
\hline Soft drinks & 300 & 0 & 0 & 900 & 900 & 0 & 0 & 0 \\
\hline Leeway & 115 & 115 & 115 & 115 & 115 & 115 & 115 & 115 \\
\hline Beans & 0 & 0 & 0 & 0 & 0 & 0 & 45 & 90 \\
\hline
\end{tabular}

The quantities of the food types in the shaded boxes vary throughout the dietary scenarios and the quantities of the other food types are constant. §Unfortified soy drink.

Scenario 2 (High-dairy): $500 \mathrm{~g}$ milk and milk products and $25 \mathrm{~g}$ cheese products were included corresponding to a high consumption of dairy products.

Scenario 3 (Milk-products): $500 \mathrm{~g}$ milk and milk products were included and cheese products were excluded. Cheese products were substituted with the same amount $(\mathrm{kJ})$ of marmalade (a realistic choice in a Scandinavian breakfast) to elucidate the role of milk products in overall nutrition (70).

Scenario 4 (Cheese-products): $25 \mathrm{~g}$ cheese products were included and milk and milk products were substituted with the same amount $(\mathrm{kJ})$ of soft drinks to elucidate the role of cheese products in overall nutrition. Soft drinks, such lemonade and coca cola, are used as alternatives to milk products, and both national and international studies have found an inverse association between intake of milk and sugar-containing soft drinks (i.e. sugar-containing soft drinks replacing milk in the diet $(25,71,72))$. Moreover, there is a high consumption of lemonade in the population (25).

Scenario 5 (Non-dairy): All dairy products were excluded. Milk and milk products were substituted with soft drinks and cheese products were substituted with marmalade in the same amount $(\mathrm{kJ})$. We wanted to assess the role of dairy products in overall health as well as their contribution to nutritional status for the major nutrients that they supply.

Scenario 6 (Soy drink): $500 \mathrm{~g}$ milk and milk products were substituted with $500 \mathrm{~g}$ unfortified soy drinks. This diet was included because of the new trend among the younger generation to consume non-dairy drinks (e.g. soy drink) as an alternative to milk (70). Alcoholic drinks were excluded to adjust for the same energy level.

Scenario 7 (Vegetarian): All meat and meat products were substituted with beans (healthy alternatives to meat) in the same amount (kJ). Dairy consumption was $500 \mathrm{~g}$ milk and milk products.

Scenario 8 (Vegan): All foods of animal origin (i.e. meat, fish, eggs, and dairy products) were excluded. To maintain the energy level, these products were substituted with soy drinks and beans. The vegan diet is oversimplified regard to nutrition. However, we include the vegan diet manly due to the fact that it is relevant when considering sustainable issues.

\section{Calculating percentages of energy and nutrients in dietary scenarios}

To create and prepare the dietary scenarios from the main food types, we calculated the nutrient composition for $100 \mathrm{~g}$ of each food type using Dankost 3,000 dietary assessment software (Dankost, Copenhagen, Denmark). This gave us the opportunity to create dietary scenarios composed of the most consumed food items, taking current food consumption patterns into account. The 21 nutrients included in the present study were the ones specified by the NNR 2004 (protein, carbohydrates, fat, vitamin $\mathrm{A}$, vitamin $\mathrm{D}$, vitamin $\mathrm{E}$, vitamin $\mathrm{C}$, vitamin $\mathrm{B} 12$, niacin, thiamin, riboflavin, vitamin B6, folate, magnesium, 
iron, zinc, phosphorus, potassium, calcium, selenium, iodine) (see tables 4 and 5) (64). The nutritional value for the food intake patterns were compared with the NNR for women aged 31-60 (64).

\section{Calculating GHGEs of dietary scenarios}

Besides estimating the total GHGE for each dietary scenario, the absolute $\left(\mathrm{g} \mathrm{CO}_{2} \mathrm{e}\right.$ per day) as well as the relative ( $\%$ of total $\mathrm{g} \mathrm{CO}_{2}$ e per day) contribution and the contribution from each food type to total diet weight were also calculated for scenario 1 with average-dairy consumption. This was included to analyze the effects of the various food types in terms of GHGE.

\section{Calculation of nutrition density in relation to GHGE}

The Nutrient Density of Climate Impact (NDCI) index, which takes into account the fact that foods contribute differently with respect to energy and nutrients, was used to estimate the nutrient density of different solid food items in relation to nutrition recommendations and climate impact (10). We included 15 different solid food items, which were representative for all food types. Nutrient density of a food item was calculated by summarizing the proportions of the recommended daily intake of each nutrient provided by $100 \mathrm{~g}$ of the food item multiplied by the proportion of nutrients contributing to more than $15 \%$ NNR. The cut-off level for a significant contribution was set according to the Codex Alimentarius Commission's health claim definition of solid food items: source of nutrients for $15 \%$ of recommended intake of a nutrient (73). The same 21 nutrients used to calculate the nutritional value from the dietary scenarios were used.

Nutrient density of food item Y

$$
\begin{aligned}
= & \sum_{21 \text { nutr }}\left(100 \times \frac{\text { Amount of nutrient } \mathrm{X} \text { in } 100 \mathrm{~g} \text { of } \mathrm{Y}}{\text { Recommended intake of nutrient } \mathrm{X}}\right) \\
& \times\left(\frac{\text { Number of nutrients in } \mathrm{Y} \geq 15 \% \text { of rec.intake }}{21}\right)
\end{aligned}
$$

NDCI index $=\left(\frac{\text { Nutrient density of } \mathrm{Y}}{\mathrm{CO}_{2} \text { e for } 100 \mathrm{~g} \text { of } \mathrm{Y}}\right)$

The NDCI was calculated for the selected solid food items by dividing the nutrient density of the food with its $\mathrm{CF}$ ( $\mathrm{g} \mathrm{CO}_{2} \mathrm{e}$ per $100 \mathrm{~g}$ food item).

Although many of the solid food items contained a broad range of nutrients, the amounts present contributed to $<15 \%$ of the daily dietary recommendation. Nutrient density was calculated for 15 different solid food items including the following: beef, pork, chicken, cheese, cod, eggs, brown and polished rice, pasta, oatmeal, broccoli, carrots, brown beans, potatoes, and bananas. The selected food items were representative for the whole diet. The nutrient contents of the food items included were taken from the Danish Food Composition database
- version 7 (National Food Institute, Technical University of Denmark) (74). Data on raw food items were used in order to minimize error and to enhance generalizability. The CF data included in the calculation of the index excluded waste at the consumer level because data on raw food items were used in the calculation of nutrient density. Food items with the highest NDCI index values are those with the highest nutrient density scores in relation to the GHGE.

Cut-off value

If the NDCI index is calculated as the nutrient density divided by the $\mathrm{CO}_{2} \mathrm{e}$ for $100 \mathrm{~g}$ of food items without including a cut-off value, the index only takes into account the amount of nutrients in a given food item. However, including a cut-off value in the model takes into account both the nutrient amount and the nutrient balance. In addition, the NDCI index is dependent on the choice of cut-off value.

\section{Statistical analysis}

Linear regression was used to assess the significance of changes in vitamin $\mathrm{D}$, selenium, and riboflavin as a function of calcium content in all dietary scenarios except the vegan diet. The vegan patterns were excluded in the linear regression, because the nutritional value of vitamin $\mathrm{D}$ and selenium were very different from the other diets representing the different dietary compositions, that is, not including fish which has a high value of vitamin $\mathrm{D}$ and selenium. P-values were evaluated at a 5\% significance level. The analyses were carried out using PROC GLM procedure in Statistical Analysis System (SAS), version 9.1 (SAS Institute, Cary, NC).

\section{Results}

\section{Dietary scenarios and nutrient content \\ Energy and macronutrients}

Table 4 shows the energy percentage of macronutrients for the dietary scenarios for women (aged 31-60). All of the created dietary scenarios, except vegetarian and vegan diet, were compliant with NNR regarding the contribution of daily-recommended intake of macronutrients (Table 4).

The percentage of energy $(\mathrm{E} \%)$ from protein was between $12 \mathrm{E}$ and $17 \mathrm{E} \%$ in all dietary scenarios compared to the NNR of $10 \mathrm{E}$ to $20 \mathrm{E} \%$ with the highest value in the high-dairy and the lowest in the non-dairy and vegan diets. The low protein content $(66 \mathrm{~g})$ in the non-dairy and vegan diets is above the recommended value. The highdairy diet resulted in $27 \%$ ( $24 \mathrm{~g}$ per day) higher protein than the non-dairy diet (Table 4).

Carbohydrates contributed with $53 \mathrm{E}$ to $60 \mathrm{E} \%$ in all dietary scenarios compared to the recommended level of $52 \mathrm{E}$ to $60 \mathrm{E} \%$ with the highest amount in non-dairy, 
Table 4. Energy percent of macronutrients for the dietary scenarios

\begin{tabular}{|c|c|c|c|c|c|c|c|c|c|}
\hline Macronutrients & NNR & Average dairy & High dairy & Milk products & Cheese products & Non dairy & Soy drink ${ }^{\S}$ & Vegetarian & Vegan \\
\hline Protein E\% & $10-20$ & 16 & 17 & 16 & 14 & 12 & 14 & 14 & 12 \\
\hline Carbohydrate E\% & $50-60$ & 54 & 53 & 55 & 57 & 59 & 58 & 59 & 60 \\
\hline Added sugar E\% & $\max 10$ & 5 & 2 & 5 & 10 & $12^{\star *}$ & $13^{\star *}$ & 5 & 7 \\
\hline Fat E\% & $25-30$ & 26 & 27 & 26 & 26 & 25 & 28 & $23^{*}$ & $24^{*}$ \\
\hline Saturated fat E\% & $\max 10$ & 8 & 8 & 7 & 7 & 6 & 7 & 6 & 5 \\
\hline Monounsaturated E\% & $10-15$ & 9* & 9* & $9 *$ & 9* & $9^{*}$ & $9^{*}$ & $8^{*}$ & $8^{*}$ \\
\hline Polyunsaturated E\% & 5 to 10 & 6 & 6 & 6 & 6 & 6 & 7 & 6 & 7 \\
\hline Alcohol E\% & $\max 5$ & 4 & 4 & 4 & 4 & 4 & 0 & 4 & 4 \\
\hline
\end{tabular}

E\%. percentage of energy; NNR: Nordic Nutrition Recommendations 2004 for women with a sedentary lifestyle with limited physical activity in the age range 3I-60. The food composition of each diet corresponds to the quantities (gram per day) represented in Table 3. All dietary scenarios were

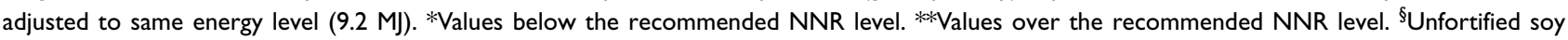
drink. The shaded columns are values below and values over the recommended NNR level.

vegetarian, and vegan diets and the lowest amount in high-dairy diets. According to NNR, the proportion of pure refined sugar types should not make up more than $10 \mathrm{E} \%$. In addition, the energy from added sugar reached the maximum in non-dairy and soy drinks, which mainly comes from soft drinks and soy drinks, respectively (Table 4).

The percentage of energy from fat should provide $25 \mathrm{E}$ to $30 \mathrm{E} \%$ according to NNR levels. The $\mathrm{E} \%$ from fat was between $23 \mathrm{E}$ and $28 \mathrm{E} \%$ with the lowest amount in the vegetarian and vegan diets and the highest amount in the soy drinks. All dietary scenarios were below the maximum level of SFA, which should be restricted to at most $10 \mathrm{E} \%$. Dairy products provided $15 \%$ of the overall SFA in the average-dairy diet. The monounsaturated fatty acid (MUFA) content of all dietary scenarios were below or in the lower level of the recommended level of $10 \mathrm{E}$ to $15 \mathrm{E} \%$, and the polyunsaturated fatty acid (PUFA) content was $6 \mathrm{E}$ or $7 \mathrm{E} \%$ compared to the NNR level of $5 \mathrm{E}$ to $10 \mathrm{E} \%$ (Table 4).

Micronutrients

Table 5 shows the content of micronutrients for the dietary scenarios for women (aged 31-60). The created dietary scenario, that is, average-dairy, high-dairy, milk products, and vegetarian diet were the ones most compliant with NNR 2004 regarding the contribution of daily recommended intake of micronutrients (Table 5).

All dietary scenarios meet the nutritional recommendations for vitamin $\mathrm{A}$, vitamin $\mathrm{E}$, vitamin $\mathrm{C}$, vitamin $\mathrm{B} 12$, niacin, thiamine, vitamin $\mathrm{B} 6$, folate, magnesium, zinc, phosphorus, and potassium (Table 5). The variation in calcium was significantly $(P=0.0001)$ correlated with the amount of dairy products in the dietary scenarios with the highest amount found in the high-dairy diet. The calcium content was below the recommended level of 800 mg per day in the diets with a low amount or without dairy products (i.e. cheese-products, non-dairy, soy drinks and the vegan diet) (Table 5). The iron content in most dietary scenarios was slightly below the recommended NNR level of $15 \mathrm{mg}$ per day except for the vegan diet. The large source of iron in the vegan diet came from beans. The non-dairy diet resulted in $3 \%(0.43 \mathrm{mg}$ per day) higher iron than the high-dairy diet (Table 5). The vitamin $\mathrm{D}$ content in all dietary scenarios was below the recommended level of $7.5 \mu \mathrm{g}$ day per day with the highest content in the high-dairy diet (Table 5). In the vegan diet, the vitamin $\mathrm{D}$, selenium, iodine, and vitamin $\mathrm{B} 12$ content was below the recommended level, mainly because of the lack of animal-based products. The iodine content in the diet that included soy drink was just below the recommended level (Table 5). The selenium and riboflavin content in the diets with low or no dairy products (i.e. cheese-products, non-dairy, soy drink, and vegan diet) were below the recommended NNR level of $40 \mu \mathrm{g} / \mathrm{day}$ and $1.1 \mathrm{mg} /$ day, respectively. The high-dairy diet had the highest content of selenium and riboflavin (Table 5).

The high-dairy diet resulted in $13 \%(0.44 \mu \mathrm{g}$ per day $)$ higher vitamin $\mathrm{D}$; $55 \%$ (645 mg per day) higher calcium; $48 \%$ ( $0.92 \mathrm{mg}$ per day) higher riboflavin, and 18\% (8.35 $\mu \mathrm{g}$ per day) higher selenium than the non-dairy diet. There was a significant correlation between changes in calcium and changes in vitamin $\mathrm{D}$ content $(P=0.0001)$, selenium $(P=0.0001)$, and riboflavin $(P=0.0001)$ throughout all the diets.

\section{Dietary GHGE}

Table 6 shows the total estimated GHGE (in $\mathrm{g} \mathrm{CO}_{2}$ e per day and $\mathrm{kg} \mathrm{CO}_{2}$ e per year) and the absolute $\left(\mathrm{g} \mathrm{CO}_{2}\right.$ e per day) contributions of food categories for the dietary scenarios including waste at the consumer level.

The estimated GHGE for the average-dairy, highdairy, milk-products, cheese-products, and non-dairy diets ranged from 4,340 to $4,826 \mathrm{~g} \mathrm{CO}_{2}$ e per day with the highest GHGE in cheese-products and lowest GHGE in milk-products (Table 6). For soy drink, the estimated 
Table 5. Nordic Nutrition Recommendations 2004 for women, and the nutritional content of the dietary scenarios

\begin{tabular}{|c|c|c|c|c|c|c|c|c|c|}
\hline Nutrients & NNR & Average dairy & High dairy & Milk products & Cheese products & Non-dairy & Soy drink ${ }^{\S}$ & Vegetarian & Vegan \\
\hline Dietary fiber (g/day) & $25-35$ & 31.4 & 31.41 & 31.41 & 31.41 & 31.41 & 31.41 & 39.31 & 47.22 \\
\hline Vitamin A (RE/day) & 700 & 1052.7 & I056.1 & 1030.7 & 1039 & 1013.6 & 1023.6 & 1028.3 & 962.7 \\
\hline Vitamin $D(\mu g /$ day $)$ & 7.5 & 3.20 & 3.34 & 3.31 & 2.94 & 2.90 & 2.90 & 2.87 & 0.1 \\
\hline Vitamin $E(\alpha-T E /$ day $)$ & 8 & 11.27 & 11.16 & 11.13 & 11.47 & 11.44 & 11.23 & 11.15 & 10.56 \\
\hline Vitamin C (mg/day) & 75 & 168.1 & 168.5 & 169.7 & 167.7 & 168.9 & 163.5 & 163.2 & 156.1 \\
\hline BI2-vitamin ( $\mu \mathrm{g} /$ day $)$ & 2 & 5.65 & 6.49 & 6.13 & 4.03 & 3.67 & 3.67 & 5.07 & 0.1 \\
\hline Niacin eug. (NE/day) & 15 & 32.6 & 33.9 & 32.4 & 29.7 & 28.1 & 29.7 & 26.9 & 24.1 \\
\hline BI-Thiamin (mg/day) & I.I & 1.52 & 1.59 & 1.57 & 1.39 & 1.38 & 1.57 & 1.47 & 1.66 \\
\hline B2-Riboflavin (mg/day) & 1.3 & 1.61 & 1.90 & 1.83 & 1.05 & 0.98 & 1.02 & 1.75 & 0.88 \\
\hline B6-vitamin (mg/day) & 1.2 & 2.05 & 2.11 & 2.10 & 1.89 & 1.88 & 2.07 & 1.95 & 1.91 \\
\hline Folate ( $\mu \mathrm{g} /$ day) & 400 & 479.3 & 486.2 & 474.7 & 463.5 & 451.9 & 586.5 & 563.4 & 706.1 \\
\hline Magnesium (mg/day) & 280 & 369 & 384 & 378 & 341 & 335 & 386 & 436 & 493 \\
\hline Iron (mg/day) & 15 & 13.39 & 13.27 & 13.34 & 13.62 & 13.7 & 14.09 & 14.86 & 17.91 \\
\hline Zinc (mg/day) & 7 & 11.39 & 12.0 & 11.09 & 10.04 & 9.13 & 9.91 & 9.11 & 7.87 \\
\hline Phosphorus (mg/day) & 600 & $|54|$ & 1696 & 1570 & 1227 & 1102 & 1258 & 1583 & 1276 \\
\hline Potassium (mg/day) & 3100 & 4081 & 4315 & 4306 & 3662 & 3654 & 3685 & 4656 & 4540 \\
\hline Calcium (mg/day) & 800 & 1011 & 1173 & 1021 & 681 & 528 & 470 & 1068 & 525 \\
\hline lodine $(\mu /$ day $)$ & 150 & 231.4 & 258.4 & 255.3 & 182.6 & 179.5 & 145 & 255 & 97.8 \\
\hline Selenium ( $\mu g /$ day) & 40 & 44.19 & 46.18 & 44.04 & 39.97 & 37.83 & 39.83 & 40.81 & 22.89 \\
\hline
\end{tabular}

NNR: Nordic Nutrition Recommendations 2004 for women with a sedentary lifestyle with limited physical activity in the age range $3 \mathrm{I}-60$. The food composition of each diet corresponds to the quantities (gram per day) represented in Table 3. All dietary scenarios were adjusted to same energy level (9.2 MJ). The shaded columns are values below the recommended NNR level. ${ }^{\S}$ Unfortified soy drink.

Table 6. The total estimated greenhouse gas emission (in $\mathrm{g} \mathrm{CO}_{2} \mathrm{e}$ per day) and the absolute contributions of food types for the dietary scenarios including waste at consumer level

\begin{tabular}{|c|c|c|c|c|c|c|c|c|}
\hline Food types & Average dairy & High dairy & Milk products & Cheese products & Non-dairy & Soy drink ${ }^{\S}$ & Vegetarian & Vegan \\
\hline Vegetables & 343 & 343 & 343 & 343 & 343 & 343 & 343 & 343 \\
\hline Fruits & 239 & 239 & 239 & 239 & 239 & 239 & 239 & 239 \\
\hline Juice & 36 & 36 & 36 & 36 & 36 & 36 & 36 & 36 \\
\hline Bread and cereals & 355 & 355 & 355 & 355 & 355 & 355 & 355 & 355 \\
\hline Potatoes, pasta, rice & 356 & 356 & 356 & 356 & 356 & 356 & 356 & 356 \\
\hline Fish & 146 & 146 & 146 & 146 & 146 & 146 & 146 & 0 \\
\hline Meat and meat products & 1335 & 1335 & 1335 & 1335 & 1335 & 1335 & 0 & 0 \\
\hline Fats & 61 & 61 & 61 & 61 & 61 & 61 & 61 & 61 \\
\hline Eggs & 55 & 55 & 55 & 55 & 55 & 55 & 55 & 0 \\
\hline Milk and milk products & 383 & 595 & 595 & 0 & 0 & 0 & 595 & 0 \\
\hline Cheese products & 243 & 221 & 0 & 221 & 0 & 0 & 0 & 0 \\
\hline Marmalade & 0 & 0 & 40 & 0 & 40 & 40 & 40 & 0 \\
\hline Water, tea and coffee & 202 & 202 & 202 & 202 & 202 & 202 & 202 & 202 \\
\hline Alcoholic drinks & 340 & 340 & 340 & 340 & 340 & 0 & 340 & 340 \\
\hline Soy drink & 0 & 0 & 0 & 0 & 0 & 215 & 0 & 129 \\
\hline Soft drinks & 300 & 0 & 0 & 900 & 900 & 0 & 0 & 0 \\
\hline Leeway & 237 & 237 & 237 & 237 & 237 & 237 & 237 & 237 \\
\hline Beans & 0 & 0 & 0 & 0 & 0 & 0 & 58 & 116 \\
\hline Sum ( $\mathrm{g} \mathrm{CO}_{2} \mathrm{e}$ per day) & 4631 & 4521 & 4340 & 4826 & 4645 & 3620 & 3063 & 2414 \\
\hline
\end{tabular}

The estimated greenhouse gas emission for the dietary scenarios corresponding to the quantities (gram per day) represented in Table 2 . The shaded boxes indicate the food types where the quantities vary throughout the dietary scenarios. ${ }^{\S}$ Unfortified soy drink. 
values were $3,620 \mathrm{~g} \mathrm{CO}_{2} \mathrm{e}$ per day. For the vegetarian and vegan diets, the estimated GHGE were 3,063 and 2,414 g $\mathrm{CO}_{2} \mathrm{e}$ per day, respectively. The average dairy diet resulted in $48 \%$ (2,217 $\mathrm{g} \mathrm{CO}_{2} \mathrm{e}$ per day) higher GHGE compared to the vegan diet and 34\% higher GHGE (1,568 $\mathrm{g} \mathrm{CO}_{2} \mathrm{e}$ per day) compared to the vegetarian diet (Table 6).

Figure 1 shows the contribution of each food type in the average-dairy diet to total diet quantity (\% of total gram per day) and to total GHGE (\% of total $\mathrm{g} \mathrm{CO}_{2} \mathrm{e}$ per day) including waste at the consumer level. The contribution of total dairy products including milk products and cheese to diet quantity $(11 \%)$ was very close to their relative contribution to total GHGE (13\%) (Figure 1). Similarly, the contribution for vegetables, fruits, and juice to diet quantity $(19 \%)$ and the contribution of bread, cereals, potatoes, pasta, and rice to diet quantity $(16 \%)$ was closer to their relative contribution to total GHGE (13 and 16\%, respectively) (Figure 1). However, the relative contribution of meat and meat products was the strongest contributor to total GHGE $(29 \%)$ whereas the contribution to diet quantity was one of the smallest $(3 \%)$. Similarly, the relative contribution of cheese to total GHGE (5\%) was also high compared with its weight contribution (1\%) (Figure 1).

\section{Nutrition density in relation to GHGE}

Table 7 shows the NDCI index for the 15 solid food items and the values used in the calculation where cheese has the highest nutrient density, brown beans the highest number of nutrients over $15 \%$ of NNR, and beef the highest GHGE compared to the other food items. Figure $2 \mathrm{a}$ and $\mathrm{b}$ shows the CF per $\mathrm{kg}$ food and the NDCI index when $15 \%$ was used as the cut-off level for nutrients with a significant contribution.

The $\mathrm{CF}$ ranged from 0.22 to $28 \mathrm{~kg} \mathrm{CO}_{2} \mathrm{e}$ per $\mathrm{kg}$ food items with the highest values for meat products, cheese, and cod and the lowest values for plant-based products such as carrots, potatoes, oatmeal, bananas, and brown beans (Figure 2a). When combining nutritional value and climate impact using the NDCI index, the ranking of food items changes and values for animal-based and plantbased products are more similar (Figure $2 b$ ). The index values for cod, pork, cheese, chicken, brown rice, pasta, and potatoes were quite similar (between 0.19 and 0.35 ) despite very different nutrient density values, reflecting different GHGE values. Cheese has the highest nutrient density value compared to all the other food items included in the study, which can be explained with regard to both the number of nutrients and their amount relative to recommendations. Beef, polished rice, and bananas have the lowest index NDCI values $(0.06,0.07$ and 0.09 , respectively). The nutrient density of beef was higher than that of bananas, but the GHGE was also higher, resulting in an almost similar index value (Table 7). The index value was highest for beans, oatmeal, and eggs (2.17, 1.49 and 1.10 , respectively). The nutrient density of eggs was close to brown beans, but the GHGE was higher, resulting in a lower index value. The nutrient density for oatmeal was much lower than that of eggs, but the GHGE were also much lower, resulting in a higher index value than eggs (Table 7). Broccoli and carrots have similar index values (0.40) despite a very low GHGE for carrots. This can be explained by a very low nutrient density value for carrots, reflecting the low amount of many nutrients relative to the dietary recommendations (Table 7).

\section{Discussion}

This study shows that excluding dairy products from our diet does not necessarily mitigate climate change; however, it may have nutritional consequences. A healthy diet

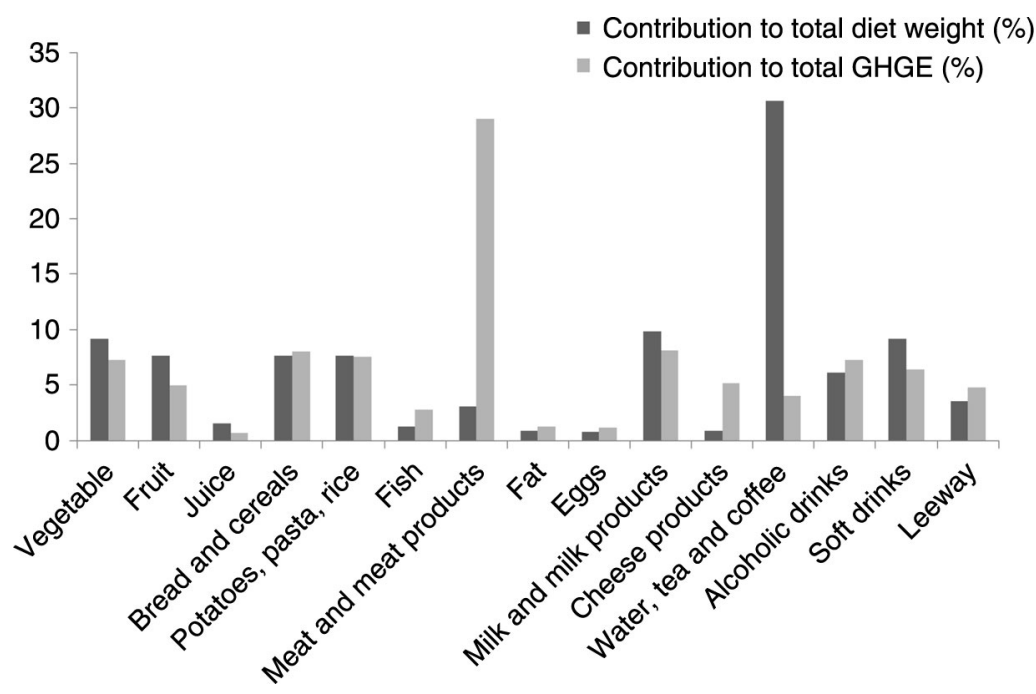

Fig. 1. The contributions of each food type in the average-dairy scenario to total diet weight ( $\%$ of total gram per day) and to total greenhouse gas emission (GHGE) (\% of total $\mathrm{g} \mathrm{CO}_{2} \mathrm{e}$ per day). Total diet weight: $3262 \mathrm{~g}$ per day; Total GHGE: $4631 \mathrm{~g} \mathrm{CO}_{2} \mathrm{e}$ per day. 
Table 7. Nutrient density in relation to climate impact for solid food items

\begin{tabular}{|c|c|c|c|c|c|}
\hline Solid food items & Number of nutrients $\geq 15 \%$ NNR & $\%$ of NNR in $100 \mathrm{~g}$ food & Nutrient density & GHGE & NDCl Index \\
\hline Beef & 9 & 389 & 166.8 & 2799 & 0.06 \\
\hline Rice, polished & 3 & 175 & 25.0 & 374 & 0.07 \\
\hline Bananas & 2 & 115 & 10.9 & 122 & 0.09 \\
\hline Chicken & 7 & 297 & 98.8 & 521 & 0.19 \\
\hline Potatoes & 2 & 138 & 13.2 & 57 & 0.23 \\
\hline Pasta & 5 & 187 & 44.5 & 193 & 0.23 \\
\hline Rice, brown & 6 & 326 & 93.1 & 374 & 0.25 \\
\hline Cheese & 11 & 545 & 285.5 & 923 & 0.31 \\
\hline Pork & 10 & 387 & 184.4 & 557 & 0.33 \\
\hline Fish, Cod & 7 & 465 & 155.0 & 447 & 0.35 \\
\hline Broccoli & 4 & 351 & 66.8 & 167 & 0.40 \\
\hline Carrot & 1 & 187 & 8.9 & 22 & 0.40 \\
\hline Eggs & 11 & 440 & 230.2 & 210 & 1.10 \\
\hline Oatmeal & 8 & 352 & 134.1 & 90 & 1.49 \\
\hline Beans, brown & 12 & 471 & 269.4 & 124 & 2.17 \\
\hline
\end{tabular}

NNR: Nordic Nutrition Recommendations; NDCl index: nutrient density to climate impact index (NDCl=nutrient density/ GHGE); nutrient density = percentage of NNR in $100 \mathrm{~g}$ of product $\times$ number of nutrients $\geq 15 \% \mathrm{NNR} / 21$; GHGE: greenhouse gas emission (gram $\mathrm{CO}_{2} \mathrm{e}$ per $100 \mathrm{~g}$ food items) excluded waste at consumer level.

can be achieved through various food combinations, which are associated with different environmental impacts (e.g. GHGE). Current dietary guidelines are based on nutrient recommendations for health and do not account for the environmental aspects of the diet. The present study highlights the importance of examining these two aspects together when considering future dietary recommendations for a sustainable diet. If the main focus is solely on a reduction in diet-related GHGE, then reductions in animal-based food, which make the greatest contribution to GHGE in our diet, may result in a lower diet related GHGE $(4,6,8)$. This is in agreement with new research from the United States, where a study shows a lower GHGE when comparing vegetarian and vegan diets with animal-based diets (75). Not all of these diets meet the dietary recommendations of a healthy population (75). However, some studies have shown that it is possible to decrease GHGE without health consequences $(11,12)$. This study shows that reducing consumption of food items with high or relative high GHGE is not necessarily the best approach to decreasing diet-related GHGE. Where substituting a product in an isocaloric approach, the resulting variations in diet-related GHGE depend both on the GHGE per kg of the substituted product and also its energy density. If a product is replaced by food with lower energy density, the quantity needed to compensate for the caloric loss is greater than the quantity removed. This may result in a higher diet-related GHGE despite the lower GHGE per $\mathrm{kg}$ of the substituted product. This is in agreement with a French study showing that the isocaloric substitution of meat with fruit and vegetables results in either no reduction or even an increase in GHGE, because the required amounts of fruit and vegetables to maintain the caloric content of the diet were relatively high (6). However, the relatively high variability of diet-related GHGEs within the high-nutritional quality class suggests that some individuals have diets with both high energy density and low GHGEs (76). More research is therefore needed to evaluate the feasibility of adopting sustainable dietary patterns in everyday life.

On a per $\mathrm{kg}$ basis, dairy products have a relatively high $\mathrm{CF}$, but at the same time they have a high nutritional value. This study confirms that it could be difficult to fulfill the recommended daily intake of, in particular, calcium if dairy products are excluded from our diet. For example, according to own calculations, $1,300 \mathrm{~g}$ of the vegetable food type or $700 \mathrm{~g}$ of broccoli should be included in the non-dairy diet in order to reach the recommended intake of calcium (data not shown). The created dietary scenarios, that is, average-dairy, high-dairy, milk-products, and vegetarian (including dairy products) diet were the ones most compliant with NNR. A reduction in the intake of dairy products may be considered in the context of the whole diet to ensure that substitutions made in the diet are appropriate with respect to health. The bioavailability of some minerals (e.g. calcium) is an importance aspect to be considered. Plant-based products containing compounds, for example, phytates and oxalates, can inhibit the absorption of some minerals (e.g. calcium) (77), and there are only a few green vegetables and dried fruits that are good sources of calcium (78). Another aspect to take into account when comparing protein with animal sources and vegetable protein is the quality of the protein. All of the dietary scenarios in this study have adequate protein 
a)

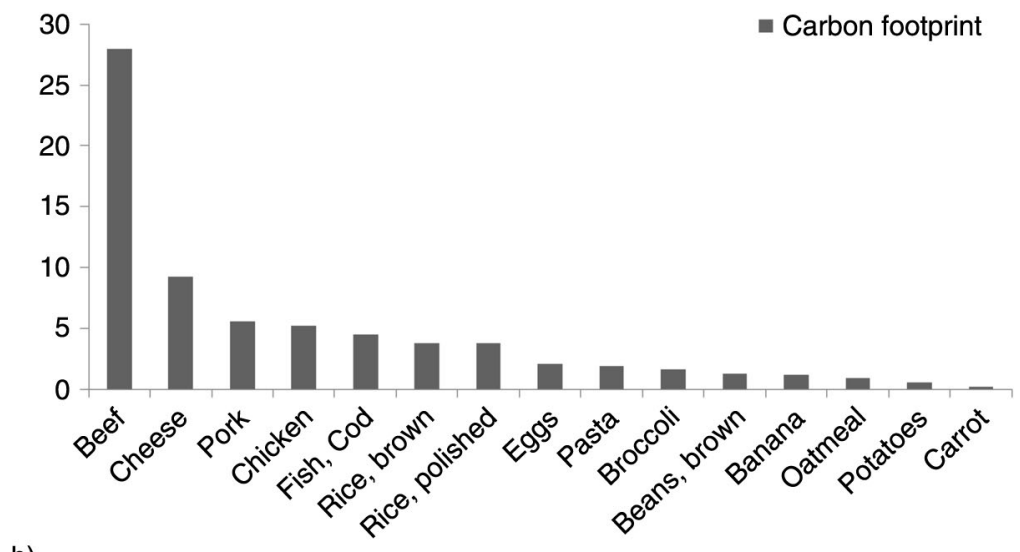

b)

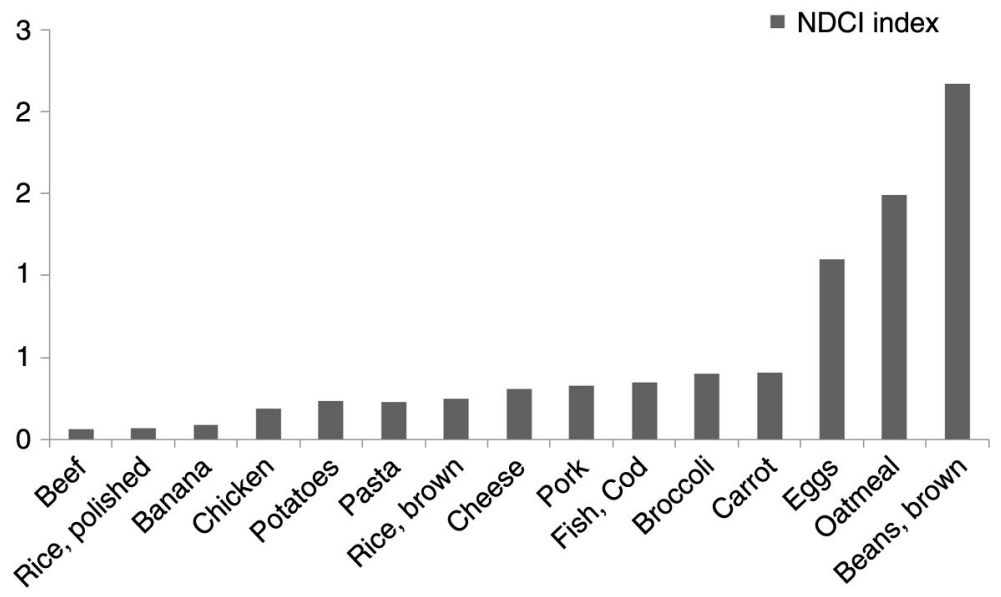

Fig. 2. NNR: Nordic Nutrition Recommendations; (a) Carbon footprint ( $\mathrm{kg} \mathrm{CO}_{2} \mathrm{e}$ per $\mathrm{kg}$ solid food item) excluding waste at consumer level. (b) NDCI index: nutrient density to climate impact index (NDCI = nutrient density/GHGE); nutrient density $=$ percentage of NNR in $100 \mathrm{~g}$ of product $\times$ number of nutrients $\geq 15 \% \mathrm{NNR} / 21$; GHGE: greenhouse gas emission (gram $\mathrm{CO}_{2} \mathrm{e}$ per $100 \mathrm{~g}$ food item) excluding waste at consumer level.

content. However, dairy products are sources of highquality protein together with eggs, meat, and fish. Dairy proteins are mostly composed of casein, which is well known for high nutritional value and physiological properties $(79,80)$. The high level of lysine makes casein and total milk protein an important complement for many plant proteins that normally have limited amounts of lysine (81). When planning a vegan diet, the minimum requirement of protein should be higher compared to an animal-based diet to account for decreased protein bioavailability in vegetarian foods $(82,83)$. However, preparation of some plant foods and cooking reduces the amount of antinutrition (trypsin inhibitors, etc.), thus increasing the bioavailability of protein (84). Although dairy products are low in vitamin $\mathrm{D}$, a recent study from Canada revealed that people who consume milk more than once a day show a higher level of vitamin $D$ than those who do so less than once a day (85). On the contrary, dairy fat accounted for about $30 \%$ of the total SFA intake in Denmark in 2003 (23). However, this study indicates that there is room for low-fat dairy products in a healthy diet.
Models to integrate the environmental impact with their inherent nutritional value are being developed. The NDCI index is one such example. The aim of the index is to identify desirable food items that are both sustainable and also have maximum nutritional value. Calculations of nutrient density are based on nutrient density models described by Drewnowski (86). The intention is to distinguish food items that are energy dense from those that are rich in nutrients. There have been several attempts to formally define what is meant by nutrientrich food and some of these considerations have been accounted for and incorporated into the NDCI index. In 1974, the Federal Trade Commission (FTC) proposed to limit the use of the term 'nutritious' for food that provides $\geq 10 \%$ of the US recommended dietary allowances (RDA) for protein and three other nutrients per $100 \mathrm{kcal}$ (87). However, only one vegetable and one milk product, out of a total of 135 different foods, met those criteria (88). Another study suggested that the designated food ought to provide $50 \%$ of the US RDA for one nutrient, $20 \%$ for two nutrients, $15 \%$ for three nutrients, 
$10 \%$ for four nutrients, and $6 \%$ for five nutrients (89). However, these criteria were also so strict that very few food items could fulfill these requirements. Similarly, one author proposed an index ranging from 0 to 100 points, where each nutrient was rated according to a 5-point scale: food items containing $>20 \%$ of daily value (DV) were assigned 100 points, those containing $17-19 \%$ of DV got 75 points, those containing $14-16 \%$ got 50 points, those containing $10-13 \%$ got 25 points, and those containing $<10 \%$ got 0 points (90).

When considering the $\mathrm{CF}$ in relation to various food products' nutrient density, meat from monogastric animal (e.g. pork, chicken) and cheese, which generally have the highest $\mathrm{CF}$ per $\mathrm{kg}$ product, were more similar to plantbased products. It is worth remembering that the index has some limitations, for example, due to the selection of nutrients, considerations of protein quality, bioavailability of nutrients, and the choice of criteria for setting the threshold values. However, introduction of the index contributes with new knowledge within the field of combining nutritional value and climate impact. Countries that have started to produce guidelines that combine dietary recommendations for health with a reduction in environmental impact focus on broad food groups $(91,92)$. Although, this is an important step forward, the next step is to consider what the whole diet might look like. A well-balanced diet is important when reducing GHGE and meeting dietary recommendations for health, and can be achieved without eliminating meat or dairy products $(11,12)$. However, these products must be consumed in smaller quantities $(11,12)$.

The dietary scenarios in the present study were created in a realistic and objective way by including the most frequently consumed food items in the diet of the Danish population in the same proportion as they are currently eaten. However, the vegan diet was oversimplified, which may have influenced the nutritional value of the diet. Furthermore, alcohol was excluded in the soy drink diet to match the total energy (9.2 MJ), which was a limitation. We made assumptions about the approximate quantities and composition of some food types if the information available was inadequate. The quantities of dairy products included in this study were realistic according to the USDA's dietary guidelines and the Danish average consumption. A further increase of these products is not necessary to meet dietary recommendations. Finally, generalizability of the results is limited when only women in a certain age group are included.

Comparing $\mathrm{CF}$ values for different studies is complex due to, among other things, methodological choices, uncertainties in data, and various assumptions behind the calculated $\mathrm{CF}$ values (choice of data sources, how are system boundaries defined, etc.). However, we have considered thoroughly all of these issues and accounted for to the greatest possible extent in the present study.
For example, in many CF studies the consumer stage is not included. To harmonize the system boundaries, the latter stage of the life cycle (transport from retail to consumer and, if relevant, preparation of the food) was added in our study. For some food items, GHGE data were not available in the literature and in those cases assumptions had to be made. The values calculated in our study seem to be compatible with the findings of other studies $(6,7)$.

Combining nutritional value and sustainability aspects - in the present paper limited to GHGE - is one step toward finding a more accurate way to address sustainable food consumption. However, future studies of sustainable food consumption need to focus further on dietary recommendations for health, as well as on a broader range of environmental impact categories. Accordingly, aspects such as protein quality, water use, land use change, eutrophication, and impact on biodiversity need further investigation. In addition, the role of livestock in sustainable food production requires more exploration, as there can be both positive as well as negative impacts associated with animal production. One of the greatest challenges to supply the growing population with nutritious food in the future is the competition of the limited land resource. Here, cattle have the ability to convert grass to valuable food products such as milk and meat and make use of land areas (rangelands) less suitable for direct food crops. Cattle might thereby play an important role also in our future food system, in order to use our resources as efficiently as possible.

In conclusion, this study shows that excluding dairy products from our diet does not necessary mitigate climate change but in contrast may have diametrical nutritional consequences. In addition, when optimizing a diet with regard to sustainability it is crucial to account for the nutritional value and not solely focus on impacts per kg products.

\section{Acknowledgements}

We acknowledge the financial support from Arla Food amba.

\section{Conflicts of interest and funding}

There is no conflict of interest.

\section{References}

1. Gussow J, Clancy K. Dietary guidelines for sustainability. J Nutr Educ 1986; 18: 1-5.

2. Coley D, Goodliffe E, Macdiarmid J. The embodied energy of food: the role of diet. Energ Pol 1998; 26: 455-9.

3. International Scientific Symposium. Biodiversity and sustainable diets - united against hunger. Food and Agriculture Organization of the United Nations. Rome, Italy: FAO Headquarters; 2010. 
4. Carlsson-Kanyama A, Gonzalez AD. Potential contributions of food consumption patterns to climate change. Am J Clin Nutr 2009; 89: 1704S-9.

5. Ministry of the environment. 2008. http://www.ymparisto.fi/ default.asp?contentid=62075\&lan=en [cited 2 January 2013].

6. Vieux F, Darmon N, Soler LG. Greenhouse gas emissions of self-selected individual diets in France: changing the diet structure or consuming less? Ecol Econ 2012; 75: 91-1.

7. Risku-Norja H, Kurppa S, Helenius J. Dietary choices and greenhouse gas emissions - assessment of impact of vegetarian and organic options at national scale. Prog Ind Ecol 2009; 6: 340-54.

8. Wallén A, Brandt N, Wennersten R. Does the Swedish consumer's choice of food influence greenhouse gas emissions? Environ Sci Pol 2004; 7: 525-35.

9. Millward DJ, Garnett T. Plenary lecture 3: food and the planet: nutritional dilemmas of greenhouse gas emission reductions through reduced intakes of meat and dairy foods. Proc Nutr Soc 2010; 69: 103-18.

10. Smedman A, Lindmark-Mansson H, Drewnowski A, Edman AK. Nutrient density of beverages in relation to climate impact. Food Nutr Res 2010; 54: 1-8.

11. Macdiarmid J, Kyle J, Horgan G, Loe J, Fyfe C, Johnstone A, et al. Live-well: a balance of healthy and sustainable food choices. WWF Report. Scotland: WWF; 2011.

12. Macdiarmid J, Kyle J, Horgan GW, Loe J, Fyfe C, Johnstone A, et al. Sustainable diets for the future: can we contribute to reducing greenhouse gas emissions by eating a healthy diet? Am J Clin Nutr 2012; 96: 632-9.

13. Barbieri HE, Lindvall C. Swedish Nutrition Recommendations Objectified (SNO) - basis for general advice on food consumption for healthy adults. Report No. 20/2005. Sweden: National Food Administration; 2003.

14. National Nutrition Council (2005). Finnish nutrition recommendations 2005. http://www.ravitsemusneuvottelukunta.fi/portal/ en/nutrition_recommendations/ [cited 2 January 2013].

15. U.S. Department of Agriculture and U.S. Department of Health and Human Services. Dietary Guidelines for Americans, 2010. Washington, DC: U.S. Government Printing Office; 2010.

16. Hjerpsted J, Leedo E, Tholstrup T. Cheese intake in large amounts lowers LDL-cholesterol concentrations compared with butter intake of equal fat content. Am J Clin Nutr 2011; 94: 1479-84

17. Siri-Tarino PW, Sun Q, Hu FB, Krauss RM. Meta-analysis of prospective cohort studies evaluating the association of saturated fat with cardiovascular disease. Am J Clin Nutr 2010; 91: 535-46.

18. Tholstrup T. Dairy products and cardiovascular disease. Curr Opin Lipidol 2006; 17: 1-10.

19. Tholstrup T, Hoy CE, Andersen LN, Christensen RD, Sandstrom B. Does fat in milk, butter and cheese affect blood lipids and cholesterol differently? J Am Coll Nutr 2004; 23: 169-76.

20. Wood R, Kubena K, O'Brien B, Tseng S, Martin G. Effect of butter, mono- and polyunsaturated fatty acid-enriched butter, trans fatty acid margarine, and zero trans fatty acid margarine on serum lipids and lipoproteins in healthy men. J Lipid Res 1993; 34: 1-11.

21. Huth PJ, Park KM. Influence of dairy product and milk fat consumption on cardiovascular disease risk: a review of the evidence. Adv Nutr 2012; 3: 266-85.

22. Elwood PC, Pickering JE, Givens DI, Gallacher JE. The consumption of milk and dairy foods and the incidence of vascular disease and diabetes: an overview of the evidence. Lipids 2010; 45: 925-39.
23. Pedersen AN, Fagt S, Groth MV, Christensen T, Biltoft-Jensen A, Matthiessen J, et al. Dietary habits in Denmark 2003-2008. Søborg: National Food Institute, Technical University of Denmark; 2010.

24. Astrup A, Andersen NL, Stender S, Trolle E. The Danish Dietary Recommendations 2005. Denmark: Ernæringsrådet og Danmarks Fødevareforskning; 2005.

25. Fagt S, Biltoft-Jensen A, Matthiessen J, Groth MV, Christensen T, Trolle E. Dietary habits of Denmark 1995-2006 - status and development with focus on fruits, vegetables and added sugar. Søborg: National Food Institute, Technical University of Denmark; 2008.

26. Audsley E, Brander M, Chatterton J, Murphy-Bokern D, Webster C, Williams A. How low can we go? An assessment of greenhouse gas emissions from the UK food system and the scope to reduce them by 2050. WWF-UK; 2009.

27. Foley J, Ramankutty N, Brauman K, Cassidy E, Gerber J, Johnston M, et al. Solutions for a cultivated planet. Nature 2011; 478: 337-42.

28. International Organization for Standardization I (2006). Environmental management - life cycle assessment - principles and framework. 14040:2006(E). Geneva, Switzerland: International Organization for Standardization.

29. International Organization for Standardization I (2006). Environmental management - life cycle assessment - requirements and guidelines. 14044:2006(E). Geneva, Switzerland: International Organization for Standardization.

30. Forster P, Ramaswamy V, Artaxo P, Berntsen T, Betts R, Fahey $\mathrm{DW}$, et al. Changes in atmospheric constituents and in radiative forcing. In: Solomon S, Qin P, Manning M, Chen Z, Marquism M, Averyt KB, Tignor M, Miller HL, eds. Climate change 2007: the physical science basis. Contribution of Working Group I to the Fourth Assessment Report of the Intergovernmental Panel on Climate Change. Cambridge, UK and New York: Cambridge University Press; 2007. pp. 42-51.

31. Sonnemann G, Vigon B, Baitz M, Frischknecht R, Krinke S, Suppen N, et al. The context of global guidance principles for life cycle inventories. In: Sonnemann G, Vigon B, eds. Global guidance principles for life cycle assessment databases. A basis for greener processes and products. Paris: UNEP SETAC Life Cycle Initiative; 2011. pp. 1-158.

32. Thomassen M, Dalgaard R, Heijungs R, de Boer I. Attributional and consequential LCA of milk production. Int $\mathrm{J}$ Life Cycle Assessment 2008; 13: 339-49.

33. Berlin J, Sonesson U, Tillman AM. Product chain actors' potential for greening the product life cycle: the case of the Swedish post-farm milk chain. J Ind Ecol 2008; 12: 95-110.

34. Röös E. Using the carbon footprint to choose between pasta and potatoes. Conference Proceedings of 3rd NorLCA Symposium; Helsinki; September 15, 2011.

35. Nilsson K, Lindberg U. Klimatpåverkan i kylkedjan - från livsmedelsindustri till konsument. Sweden: Livsmedelsverket; 2011.

36. Sonesson U, Anteson F, Davis J, Sjödén P-O. Home transport and wastage: environmentally relevant household activities in the life cycle of food. Ambio 2005; 34: 371-5.

37. Carlsson-Kanyama A, Boström-Carlsson K. Energy use for cooking and other stages in the life cycle of food a study of wheat, spaghetti, pasta, barley, rice, potatoes, couscous and mashed potatoes. Sweden: Stockholm University; 2001.

38. Angervall T, Florén B, Ziegler F. Vilken bukett broccoli väljer du? Stockholm: SIK - The Swedish Institute for Food and Biotechnology på uppdrag av konsumentföreningen; 2006.

39. Berlin J, Sund V. Klimatpåverkan från glassprodukter. SIK Report No. 796. Gothenburg: The Swedish Institute for Food and Biotechnology; 2009. 
40. Cederberg C, Sonesson U, Henriksson M, Sund V, David J. Greenhouse gas emissions from Swedish production of meat, milk and eggs 1990 and 2005. SIK Report No. 793. Gothenburg: The Swedish Institute for Food and Biotechnology; 2009.

41. Davis J, Wallman M, Sund V, Emanuelsson A, Cederberg C, Sonesson U. Emissions of greenhouse gases from production of horticultural products. Analysis of 17 products cultivated in Sweden. Report No. SR 828. Gothenburg, Sweden: SIK - The Swedish Institute for Food and Biotechnology; 2011.

42. Flysjö A, Cederberg C, Stris I. LCA-databas för konventionella fodermedel - miljöpåverkan i samband med produktion. Version 1.1 (LCA database for conventional feeds - environmental impact related to production. Version 1.1; in Swedish). Report No. 772. Gothenburg, Sweden: SIK - The Swedish Institute for Food and Biotechnology; 2008.

43. Flysjö A. Greenhouse gas emissions in milk and dairy product chains. Improving the carbon footprint of dairy products. Tjele, Denmark: Science and Technology, Aarhus University, 2012.

44. Halberg N, Dalgaard R, Dalgas Rasmusen M. Miljøvurdering af konventionel og økologisk avl af grøntsager. Livscyklusvurdering af produktion i væksthuse og på friland: Tomater, agurker, løg, gulerødder. Report No. 5. Miljøstyrelsen; 2006.

45. Landquist B. Jämförelse av klimatpåverkan för ekologiska resp. IP-odlande gröna ärter. SIK Report No. 838. Gothenburg: The Swedish Institute for Food and Biotechnology; 2012.

46. Lorentzon K, Nilsson K. LCA-data på apelsinjuise - version 4. SIK Report No. P80448. Gothenburg: The Swedish Institute for Food and Biotechnology; 2009.

47. LRF 2002. Maten och miljön, Livscykelanalys av sju livsmedel (Food and the environment, lifecycle assessment of seven food items). Skövde, Sweden.

48. Luske B. Comprehensive carbon footprint assessment. Waddinxveen, The Netherlands: Soil \& More International; 2010.

49. Mogensen L, Knudsen MT, Hermansen JE. Fødevarernes klimaaftryck. Tjele, Denmark: Department of Agroecology, Science and Technology, Aarhus University; 2009.

50. Mogensen L, Kidmose U, Hermansen JE. Baggrundsnotat til Fødevareministeriet: Fødevarers klimaaftryk, sammenhængene mellem kostpyramiden og klimapyramiden, samt opfang of effekt af fødevarerspild. Tjele, Denmark: Aarhus Universitet, Det Jordbrugsvidenskabelige Fakultet, Institut for Jordbrugproduktion og miljø; 2009.

51. Nielsen PH, Nielsen AM, Wiedeman BP, Dalgaard R, Halberg N. 2003. LCA food data base. www.lcafood.dk [cited 2 January 2013].

52. Nilsson K. Kllimatpåverkan från bryggkaffe och snabbkaffe. Report No. UPX00221. Gothenburg, Sweden: SIK - The Swedish Institute for Food and Biotechnology; 2010.

53. Nilsson K, Flysjö A, David J, Sim S, Under N, Bell S. Comparative life cycle assessment for margarine and butter consumed in UK, Germany and France. Int $\mathbf{J}$ Life Cycle Assess 2010; 15: 916-26.

54. Röös E, Sundberg C, Hansson P-A. Uncertainties in the carbon footprint of refined wheat products: a case study on Swedish pasta. Int J Life Cycle Assess 2011; 16: 350.

55. Schmidt JH. Life assessment of rapeseed oil and palm oil. Ph.D. thesis, part 3: life cycle inventory of rapeseed oil and palm oil. Aalborg: Department of Development and Planning, Aalborg University; 2007.

56. Klimatpåverkan från bröd - kommunikationsunderlag. SIK Report No. P80427. Utdrag ur rapporten till brödinstitutet januari 2009; Gothenburg: The Swedish Institute for Food and Biotechnology; 2009.
57. Klimatpåverkan av chips, läsk och godis. Utdrag ur rapport till Livsmedelsverket med finansiering av Nordiska ministerrådet; SIK Report No. P80683. Gothenburg: The Swedish Institute for Food and Biotechnology; 2010.

58. Sonesson U, Cederberg C, Flysjö A, Carlsson B. Livscykelanalys (LCA) av svenska ägg. SIK Report No. 783. Gothenburg: The Swedish Institute for Food and Biotechnology; 2008.

59. Sonesson U, David J, Ziegler F. Food production and emissions of greenhouse gas emissions. An overview of the climate impact of different productions groups. Gothenburg: SIK - The Swedish Institute for Food and Biotechnology; 2010. Report No. ISBN 978-91-7290-291-6.

60. Tynelius G. Carbon footprint. Lantmännen Unibake's croissant. Report No. 17900000. Horsens: Lantmännen Unibake; 2010.

61. Tynelius G. Carbon footprint. Lantmännen Unibake's beguette. Report No. 15470000. Horsens: Lantmännen Unibake; 2010.

62. Gustavsson J, Sonesson U, van Otterdijk R, Meybeck A. Global food losses and food waste. Rome, Italy: Food and Agriculture Organization of the United Nations; 2011.

63. WRAP. Household food and drink waste in the UK. Report prepared by WRAP. Banbury, UK: WRAP; 2009.

64. Nordic Council of Ministers. Nordic nutrition recommendations. Integrating nutrition and physical activity. Norway: Nordic Council of Ministers; 2004.

65. Hallund J, Dragsted OL, Halkjær J, Madsen C, Ovesen L, Rasmussen $\mathrm{HH}$, et al. Fruits, vegetables and health - an update of the scientific basis of the Danish recommendation. Denmark: Fødevaredirektoratet; 2002.

66. Ovesen L. Kødindtaget i Danmark og dets betydning for ernæring og sundhed. Denmark: Fødevaredirektoratet, Afdeling for Ernæring; 2002.

67. Gray J, Griffin B. Eggs and dietary cholesterol - dispelling the myth. BNF Nutr Bull 2009; 34: 66-70.

68. Fødevarerstyrelsen. 2010. http://www.altomkost.dk/Fakta/Fedt/ Fedtstoffer/forside.htm [cited 2 January 2013].

69. Pedersen AN, Fagt S, Groth MV, Christensen T, Biltoft-Jensen A, Matthiessen J, et al. Dietary habits in Denmark 2003-2008. Rosendahls - Schultz Grafisk A/S; 2010.

70. Statistics Denmark (Danmarks Statistik). 2013. http://www.statis tikbanken.dk/statbank5a/default.asp?w=1311 [cited 2 January 2013].

71. Fagt S, Matthiessen J, Biltoft-Jensen A, Groth MV, Christensen T, Hinsch H-J, et al. Udviklingen i danskernes kost 1985-2001. Med fokus på sukker og alkohol samt motivation og barrierer for sund livsstil. Denmark: Danmarks Fødevare- og Veterinærforskning; 2004.

72. Vartanian LR, Schwartz MB, Brownell KD. Effects of soft drink consumption on nutrition and health: a systematic review and meta-analyses. Am J Publ Health 2007; 97: 667-75.

73. Codex Alimentarius Commission. Nutrition and health claims (CAC/GL 23-1997). Rome, Italy: World Health Organization and the Food and Agriculture Organization of the United Nations; 1997.

74. National Food Institute - Technical University of Denmark. 2009. http://www.foodcomp.dk/v7/fcdb_default.asp [cited 2 January 2013].

75. Berners-Lee M, Hoolohan C, Cammack H, Hewitt CN. The relative greenhouse gas impact of realistic dietary choices. Energ Pol 2012; 43: 184-90.

76. Vieux F, Soler LG, Touazi D, Darmon N. High nutritional quality is not associated with low greenhouse gas emissions in self-selected diets of French adults. Am J Clin Nutr 2013; 97 : $569-83$.

77. Weaver CM, Plawecki KL. Dietary calcium: adequacy of a vegetarian diet. Am J Clin Nutr 1994; 59: 1238S-41S. 
78. Guéguen L, Pointillart A. The bioavailability of dietary calcium. J Am Coll Nutr 2000; 19: 119S-36S.

79. Bos C, Gaudichon C, Tome D. Nutritional and physiological criteria in the assessment of milk protein quality for humans. J Am Coll Nutr 2000; 19: 191S-205S.

80. Friedman M. Nutritional value of proteins from different food sources. A review. J Agric Food Chem 2012; 44: 6-29.

81. Young VR, Pellett PL. Plant proteins in relation to human protein and amino acid nutrition. Am J Clin Nutr 1994; 59: 1203S-12S.

82. Kniskern MA, Johnston C. Protein dietary reference intakes may be inadequate for vegetarians if low amounts of animal protein are consumed. Nutrition 2011; 27: 727-30.

83. Department of Health. Dietary reference values of food energy and nutritions for the United Kingdom. London, UK: HMSO; 1991.

84. Ibrahim SS, Habiba RA, Shatta AA, Embaby HE. Effect of soaking, germination, cooking and fermentation on antinutritional factors in cowpeas. Nahrung 2002; 46: 92-5.

85. Langlois $\mathrm{K}$, Greene-Finestone L, Little J, Hidiroglou N, Whiting S. Vitamin D status of Canadians as measured in the 2007 to 2009 Canadian Health Measures Survey. Health Rep 2010; 21: 47-55.

86. Drewnowski A. Concept of a nutritious food: toward a nutrient density score. Am J Clin Nutr 2005; 82: 721-32.
87. US Federal Trade Commission. 1974. http://www.ftc.gov [cited 2 January 2013].

88. Guthrie HA. Concept of a nutritious food. J Am Diet Assoc 1977; 71: 14-18.

89. Burroughs AL. FTC's proposed food advertising rule. A case of comprehensive complexity. Food Technol 1975; 29: 30.

90. Padberg D, Kubena K, Ozuna T, Kim H, Osborn L. The nutritional quality index: an instrument for communicating nutrition information to consumers. College Station, TX: Texas A\&M University; 1993.

91. Barilla center for food and nutrition. Double pyramid: healthy food for people, sustainable food for the planet. Parma, Italy: Barilla Center for Food and Nutrition; 2010.

92. U.S. Department of Health and Human Services, U.S. General services administration. Health and sustainability guidelines for federal concessions and vending operations. Atlanta, GA: Centers for Disease Control and Prevention; 2010.

*Louise Bruun Werner

Department of Nutrition, Exercise and Sports

Faculty of Sciences

University of Copenhagen

DK-II65 Copenhagen, Denmark

Email: lbw@life.ku.dk 